\title{
CORRIGENDUM
}

\section{Small-molecule inhibitors targeting the DNA-binding domain of STAT3 suppress tumor growth, metastasis and STAT3 \\ target gene expression in vivo}

W Huang, Z Dong, Y Chen, F Wang, CJ Wang, H Peng, Y He, G Hangoc, K Pollok, G Sandusky, X-Y Fu, HE Broxmeyer, Z-Y Zhang, J-Y Liu and J-T Zhang

Correction to: Oncogene (2016) 35, 783-792; doi:10.1038/ onc.2015.215; published online 15 June 2015

Since the publication of the above article the authors have identified a number of errors in Supplemental Table S1: Chemical properties of inS3-54 and its analogues. The corrections made are listed below:

The formula for $\mathrm{A} 3$ has been amended to $\mathrm{C}_{28} \mathrm{H}_{18} \mathrm{Cl}_{2} \mathrm{~N}_{2} \mathrm{O}_{4}$ from $\mathrm{C}_{28} \mathrm{H}_{18} \mathrm{CIN}_{2} \mathrm{O}_{4}$.

The structure of $\mathrm{A} 30 \mathrm{R} 1$ has been amended.
The structure of A55 R2 has been amended.

The formula for $A 58$ has been amended to $\mathrm{C}_{24} \mathrm{H}_{17} \mathrm{Cl}_{2} \mathrm{NO}_{2}$ from $\mathrm{C}_{24} \mathrm{H}_{17} \mathrm{ClN}_{2} \mathrm{O}_{2}$.

The structure of A63 R1 has been amended.

The amended table is available online.

The authors wish to apologise for any inconvenience caused. 